\title{
GENOTYPE $\times$ ENVIRONMENT INTERACTION OF SOME TRAITS IN SUNFLOWER (HELIANTHUS ANNUUS L.) LINES
}

\author{
RAdić, V. - BAlalić, I. - Miladinov, Z. - ĆIRIĆ, M. - VASILJEVIĆ, M. - Jocić, S. - \\ MARJANOVIĆ-JEROMELA, A. \\ Institute of Field and Vegetable Crops, Maksima Gorkog 30, Novi Sad 21000, Serbia \\ (phone: +381-21-489-8100, fax: +381-21-641-3833 \\ *Corresponding author \\ e-mail: velimir.radic@nsseme.com; phone: +381-64-820-5743; fax: +381-21-641-3833 \\ (Received $9^{\text {th }}$ Oct 2019; accepted $4^{\text {th }}$ Dec 2019)
}

\begin{abstract}
The evaluation of genotype $\times$ environment interaction $(\mathrm{G} \times \mathrm{E})$ is an important component of the selection process in multi-environment trials. The objective of this study was to analyze the $\mathrm{G} \times \mathrm{E}$ interaction for seed yield (SY), germination rate (GR), thousand seed weight (TSW) and protein content (PC) of 18 sunflower parental lines through the application of AMMI analysis, as well as to identify suitable sunflower parental lines with both high performance and high stability. Highly significant differences for SY, GR, TSW and PC were found for main effects (genotypes, years). For all investigated traits $\mathrm{G} \times \mathrm{E}$ interaction was also highly significant, suggesting a different response of genotypes across testing environments. Highest SY was shown by genotypes G12, G14 and G17. Most stable lines for seed yield were G1, G2, G18 and G17. High stability in terms of GR showed the genotypes G3, G11 and G15, with average values higher than the general average. In the three-year experiment environment E3 was most stable for GR. Genotypes G2, G4, G5, G6 and G7 were stable for TSW. Similar average values and stability for TSW showed E2 and E3. The lines with the most stable reaction in the examined environmental conditions for PC were G7 and G10. The most stable environment for PC was E3.

Keywords: AMMI analysis, germination rate, protein content, 1000 seed weight, seed yield
\end{abstract}

\section{Introduction}

Sunflower (Helianthus annuus L.), with soybean (Glycine max (L.) Merr.) and rapeseed (Brassica napus L.), are some of the most important crops grown in the world and used as edible oil (Rauf et al., 2017; Kaya et al., 2019; Mahmood et al., 2019). It is arousing the interest of the producers, due to the possibility of using its oil as human food or as raw material for industrial purposes (Sabaghnia et al., 2016). High and stable yields are characteristics of greatest importance in commercial production. In the production of sunflower seed despite the yield, seed quality is very important. The primary goal of sunflower seed production is the production of genetically and physically pure seeds which are physiologically mature and healthy and have high germination rate as well as tolerance to agro-ecological stress (Miklič et al., 2011). Success in sunflower growing and production depends not only on the genetic potential of the genotype but also on environmental conditions (Denčić et al., 2011). Knowing how environmental factors impact plant growth and development would reduce the possibility of sustaining significant yield and seed quality losses (Marjanović-Jeromela et al., 2011). The use of genotype main effect plus genotype-by-environment interaction biplot analysis by plant breeders and other agricultural researchers has increased dramatically during the past decade for analyzing multi-environment trial data (Yan et al., 2007).

The researchers very often ignore interaction in the recommendation for growing some hybrids. As the interaction is present in agriculture, it is necessary to use 
corresponding statistical methods for the efficient evaluation of interaction (Ceretta and van Eeuwijk, 2008). The key question of adaptive selection is how to treat mutual relations between genotype and the environment. Basic aspects of this relation concern the assessment of adaptive capacity and stability of phenotypes in different environments and the assessment of the environment's suitability as a background for selection (Marinković et al., 2011).

In multi-environment trials, it is common to measure several response variables or attributes to determine the genotypes with the best characteristics. Thus, it is important to have techniques to analyze multivariate multi-environment trial data (García-Peña et al., 2016). AMMI (additive main effects and multiplicative interaction) model can be used to analyze multiple yield trials (Oliveira et al., 2014). It is one of the most often used model (Ceretta and van Eeuwijk, 2008). This hybrid statistical model incorporates both ANOVA for the additive component and PCA (principal component analysis) for the multiplicative component (Balalić et al., 2010). Since ANOVA and PCA are part of the AMMI model, this model is more suitable for characterizing the $\mathrm{G} \times \mathrm{E}$ interaction (Oliveira et al., 2006). The other advantage of AMMI analysis is to identify the presence of crossover GE Interaction (Kadhem, 2014). The magnitude of interaction shows the influence of environmental factors on adaptability and stability, which is a desired character only when it is connected with a yield above average (Yan and Hunt, 2003). AMMI model can provide an accurate estimation of the true performance potential of genotypes to determinate the effect of different environment (Musavi et al., 2016). Multi-environment trials (MET) are an important part of breeding programs in order to select superior genotypes for the specific region, as reported by Branković et al. (2012).

This study was conducted to give more accurate investigation about the performance of 18 different sunflower parental lines in order to identify those which are most promising for better exploitation. AMMI analysis will give information on stability and genotype by environment interaction for seed yield, germination rate, thousand seed weight and protein content of sunflower lines.

\section{Materials and methods}

Field experiments were conducted during three seasons on plots where seed production of sunflower parental lines was established. Ten of them were lines based on CMS (G1-G10) and eight of them were restorer lines (G11-G18). All examined genotypes represent parental components of the best-selling sunflower hybrids of the Institute of Field and Vegetable Crops, Novi Sad, Serbia.

The test environments are not typically environments for sunflower commercial production, since idea of successful sunflower seed production can be arranged only on locations where commercial sunflower is not producing (isolation and genetic purity of parental lines are one the most important factors for good seed production). Because of these facts (conditions), in many cases, the locations where the sunflower seed production (especially in cases of sunflower parental line seed production) are characterized by worse conditions (mainly refers to the quality of the soil and weather conditions). The average temperature and rainfall for both locations are presented in Table 1.

Plants were produced on two different soil types: pseudogley (location 1; $\mathrm{pH}$ is 5.96.5) and degraded chernozem (Location 2; pH 6.2-6.6); the soil is fertilized with $400 \mathrm{~kg}$ of complex fertilizer NPK (15:15:15) and $250 \mathrm{~kg}$ of KAN $(27 \% \mathrm{~N})$ given during crop cultivation. 
Table 1. Average temperature $\left({ }^{\circ} \mathrm{C}\right)$ and rainfall $(\mathrm{mm})$ per month

\begin{tabular}{|c|c|c|c|c|c|c|}
\hline \multirow{2}{*}{$\frac{\text { Temperature }\left({ }^{\circ} \mathbf{C}\right)}{\text { Year/month }}$} & \multicolumn{6}{|c|}{ Location 1} \\
\hline & April & May & June & July & August & September \\
\hline 2013 & 11.6 & 20.5 & 24.8 & 23.2 & 24.9 & 16.8 \\
\hline 2014 & 11.5 & 18.8 & 22.2 & 23.3 & 21.7 & 16.3 \\
\hline 2015 & 12.6 & 15.4 & 20.3 & 22.6 & 22.0 & 16.4 \\
\hline \multirow[t]{2}{*}{ Perennial average } & 10.9 & 15.9 & 19.4 & 21.0 & 20.5 & 16.1 \\
\hline & \multicolumn{6}{|c|}{ Location 2} \\
\hline 2013 & 10.9 & 18.8 & 23.5 & 22.3 & 23.6 & 15.6 \\
\hline 2014 & 10.9 & 17.6 & 20.8 & 22.4 & 20.5 & 15.2 \\
\hline 2015 & 12.1 & 14.5 & 19.5 & 21.3 & 20.6 & 15.6 \\
\hline Perennial average & 11.1 & 16.3 & 19.89 & 21.3 & 20.9 & 16.1 \\
\hline Rainfall (mm) & \multicolumn{6}{|c|}{ Location 1} \\
\hline Year/month & April & May & June & July & August & September \\
\hline 2013 & 9.5 & 36.9 & 43.6 & 62.3 & 15.9 & 43.7 \\
\hline 2014 & 62.8 & 143.7 & 47.3 & 37.8 & 55.3 & 71.9 \\
\hline 2015 & 98.6 & 116.1 & 87.7 & 97.9 & 91 & 46.7 \\
\hline \multirow[t]{2}{*}{ Perennial average } & 78.8 & 86.5 & 115.2 & 105.1 & 70.2 & 91.6 \\
\hline & \multicolumn{6}{|c|}{ Location 2} \\
\hline 2013 & 35.9 & 42.6 & 65.6 & 100.9 & 30 & 53.4 \\
\hline 2014 & 114.7 & 194.2 & 59.8 & 54.1 & 160.8 & 87.4 \\
\hline 2015 & 189.9 & 104.8 & 129.5 & 148.6 & 68.7 & 60.5 \\
\hline Perennial average & 80.0 & 85.3 & 120.3 & 104.7 & 78.2 & 94.2 \\
\hline
\end{tabular}

The experiments were arranged in a randomized complete block design (RCBD) with three replications. The following parameters were studied:

Seed yield (SY): Upon maturity, 10 plants were picked manually, from different locations on the plot, and seed yield per plant was determined. By the application of previously determined plant density (50.000 plants $h a^{-1}$ ), obtained seed yield per plant was determined in $\mathrm{kg} \mathrm{ha}^{-1}$ with $9 \%$ of moisture.

Samples from each replication were taken to laboratory and following parameters were studied:

Germination rate $(G)$ : Standard method. Examination of seed germination was repeated 4 times. Each time 100 seeds were used. Germination was determined after 10 days. Only naturally formed seeds were used for determination of this parameter. Germination was expressed in relative values (ISTA rules, 2014).

1000 seed weight (TSW): Examination of 1000 seed weight was repeated 4 times. Each time 100 seeds were used. The obtained value was applied to 1000 seed weight and was specified in grams.

Protein content $(P C)$ : Determined by standard Kjeldahl method with the help of VAP-50-Gerhardt apparatus. This parameter is also expressed in relative value.

Data were analyzed using two-way analysis of variance (ANOVA). The AMMI model was used to analyze the $\mathrm{G} \times \mathrm{E}$ interaction (Gauch, 1988). AMMI analysis of variance and AMMI1 biplot were done using GENSTAT computer program. 
To analyze the $G \times E$ interaction, the AMMI model was used (Gauch, 1988). The AMMI statistical model is a combination of customary analysis of variance (ANOVA) and principal component analysis (PCA). The equation $(E q . ~ I)$ of this model is:

$$
\mathrm{Y}_{\mathrm{ge}}=\mu+\alpha_{\mathrm{g}}+\beta_{\mathrm{e}}+\Sigma_{\mathrm{n}} \lambda_{\mathrm{n}} \gamma_{\mathrm{gn}} \delta_{\mathrm{en}}+\rho_{\mathrm{ge}}+\varepsilon_{\mathrm{ger}}
$$

with Yge is the trait of genotype $\mathrm{g}$ in environment $\mathrm{e} ; \mu$ is the grand mean, $\alpha \mathrm{g}$ is the genotypes deviation from grand mean and the environment deviation $\beta_{e}, \lambda n$ is the eigenvalue of PCA axis $n ; \gamma_{\mathrm{gn}}$ and $\delta$ en are the genotype and environment PCA scores for PCA axis n; $\rho$ ge is the residual of AMMI model and $\varepsilon_{\text {ger }}$ is the random error. AMMI uses ordinary ANOVA to analyze main effects and principal component to analyze the non-additive residual (interaction) left over by the ANOVA model. PCA decomposes the interaction into PCA axes 1 to $\mathrm{N}$ and residual remains if all axes are not used. If most of the $\mathrm{G} \times \mathrm{E}$ interaction sum of squares (SS) can be captured in the first N PCA axes, a reduced AMMI model, incorporating only the first $\mathrm{N}$ axes, can be used. The interaction between any genotype and environment can be estimated by multiplying the score of the interaction principal component axis (IPCA) of genotype by an environment IPCA score.

\section{Results and discussion}

\section{Seed yield (SY)}

Breeders are mainly concerned with crop yield and yield stability and this performance depends on the genetic yield potential; all those desirable genes that have been incorporated into a cultivar in the course of the breeding process (Marinković et al., 2011). According to these authors yield stability depends on the cultivar's capacity to react to environmental conditions.

On the basis of ANOVA, it can be seen that both main effects ( $G$ and $Y$ ) and interaction $(G \times Y)$ had a highly significant effect on SY. For SY, main effects and interaction were highly significant. SY was predominantly influenced by the genotype (81.62\%). Year amounted to SY with $0.38 \%$, and interaction with $18.00 \%$ (Table 2). This interaction (sums of squares) showed different performance of genotypes in the year of growing. According to Marinković et al. (2011), the results of the AMMI analysis of variance for the seed yield showed that both additive effects (genotype and environmental conditions) as well as their interaction had highly significant proportions in the total variance of the experiment.

The SY varied between $253.3 \mathrm{~kg}$ (G4) and $1415.9 \mathrm{~kg}$ (G12). The general mean germination rate of the trial was $664.07 \mathrm{~kg}$ (Table 3). Some of the genotypes had mean values over this average value. Concerning years (E) the highest mean value for SY was stated in E3 $(696.4 \mathrm{~kg})$, while the lowest in E2 $(645.2 \mathrm{~kg})$, as shown in Table 3. According to Sial and Ahmad (2000) high seed yield should not be the only criterion for stability of a genotype unless its high performance is established over the different environmental conditions. The AMMI1 graph for SY shows the difference between the lines (G) and the years (E) in the main effects and interaction. Most stable are lines G1, G2, G18 and G17 and they had also seed yield over average. There are some other stable lines, but with lowest seed yield concerning the average which was $664.7 \mathrm{~kg} / \mathrm{ha}$. E1 (the year 2013) was most stable because its value was nearest to the line of stability 
and had seed yield on the average value. E3 (the year 2015) contributed most to $\mathrm{G} \times \mathrm{E}$ interaction, having value farthest away from stability axes (Fig. 1).

Table 2. AMMI analysis of variance for seed yield (SY), germination (GR), 1000 seed weight $(T S W)$ and protein content $(P C)$ in sunflower

\begin{tabular}{c|c|c|c|c|c|c|c|c|c}
\hline \multicolumn{2}{l|}{} & \multicolumn{2}{c|}{ SY } & \multicolumn{2}{c|}{ GR } & \multicolumn{2}{c|}{ TSW } & \multicolumn{2}{c}{ PC } \\
\hline Source & DF & SS & $\%$ SS & SS & $\%$ SS & SS & $\%$ SS & SS & $\%$ SS \\
Treatments & 53 & 22484625 & & 3478 & & 38889 & & 1178.3 & \\
Genotypes (G) & 17 & $18350901^{* *}$ & 81.62 & $1294^{* *}$ & 37.21 & $35597 * *$ & 91.53 & $657.7^{* *}$ & 55.82 \\
Environments (E) & 2 & $85643^{* *}$ & 0.38 & $430^{* *}$ & 12.36 & $412^{* *}$ & 1.1 & $109.1 * *$ & 9.26 \\
Block & 6 & 402 & & 28 & & 2 & & 0.3 & \\
Interaction (GEI) & 34 & $4048081^{* *}$ & 18.00 & $1754^{* *}$ & 50.43 & $2880^{* *}$ & 7.41 & $411.5 * *$ & 34.92 \\
IPCA1 & 18 & $2702041^{* *}$ & 66.75 & $1393^{* *}$ & 79.42 & $1661^{* *}$ & 57.67 & $363.1 * *$ & 88.24 \\
IPCA2 & 16 & $1346040^{* *}$ & 33.25 & $361^{* *}$ & 20.58 & $1218^{* *}$ & 42.29 & $48.4^{* *}$ & 11.76 \\
Residuals & 0 & 0 & & 0 & & 0 & & 0 & \\
Error & 102 & 3174 & & 380 & & 54 & & 2.7 & \\
\hline
\end{tabular}

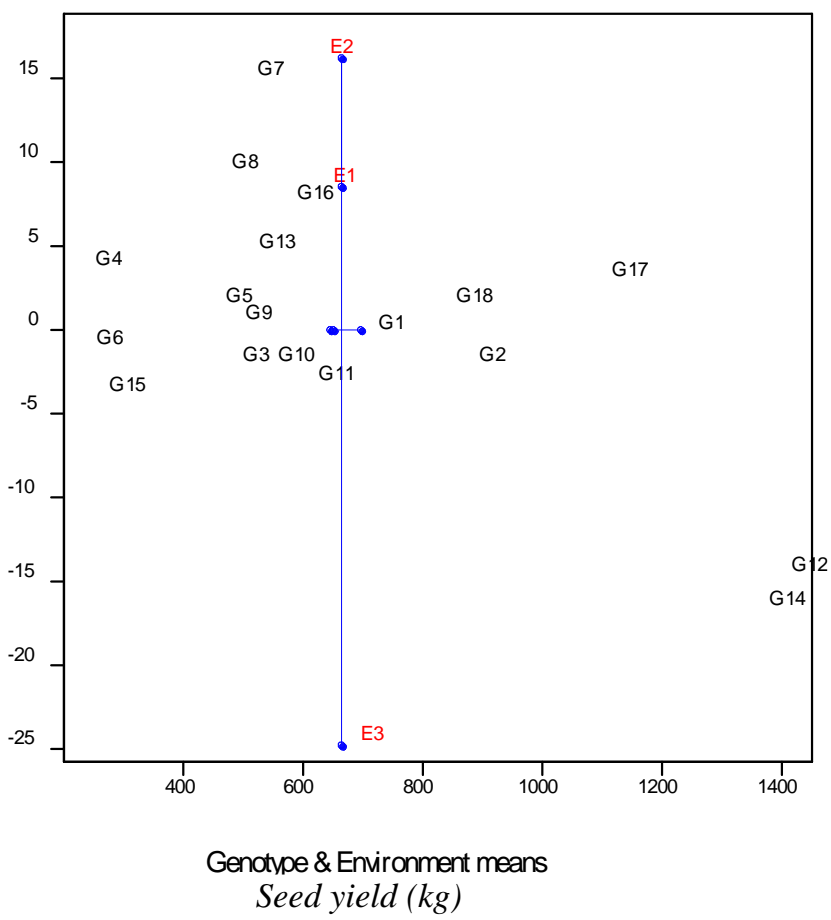

Figure 1. AMMI 1 biplot of 18 sunflower lines over three growing environments for seed yield

\section{Germination rate $(G R)$}

Understanding of $\mathrm{G} \times \mathrm{E}$ interaction in plant species is important because it has implications for economic yield and seed quality (Thangavel et al., 2011). The size of the genotype interaction $\times$ external environment $(G \times E)$ is the result of variation of uncontrolled factors, such as climate factors that are varying from year to year (Adugna and Labuschange, 2002). Germination seed under various environmental conditions and represents a critical component of the plant life cycle that is of eminent ecological and 
agronomic importance (He et al., 2014). It has been observed that a change of temperature, photoperiod, or nutrient or drought stress, during seed development, maturation, and after dispersal, may strongly affect seed performance (Donohue, 2009). On the basis of ANOVA, it can be seen that both main effects ( $G$ and $Y$ ) and interaction $(\mathrm{G} \times \mathrm{Y})$ had a highly significant effect on GR. From the main effects, genotype contributed mostly to the GR (37.21\%), and then environment (12.36\%). The interaction effect accounted for most of the sum of squares $(50.43 \%)$ indicating the substantial effect of interaction on the GR performance of the eighteen sunflower genotypes evaluated in this study. Interaction showed that the performance of genotypes responded differently to variations in the year of growing (Table 2).

Table 3. Average values for seed yield (SY) and germination rate (GR) and first IPCA (interaction principal component axis) in sunflower lines

\begin{tabular}{c|c|c|c|c}
\hline Genotype & SY $(\mathbf{k g})$ & IPCA[1] & GR $(\boldsymbol{\%})$ & IPCA[1] \\
\hline G1 & 726.3 & -0.21 & 89.00 & 1.81 \\
G2 & 894.0 & -2.13 & 80.22 & 1.74 \\
G3 & 499.3 & -2.13 & 89.33 & -0.13 \\
G4 & 253.3 & 3.62 & 88.00 & 0.61 \\
G5 & 471.3 & 1.40 & 84.00 & 1.29 \\
G6 & 255.3 & -1.11 & 87.22 & -1.27 \\
G7 & 523.9 & 14.94 & 86.44 & 0.84 \\
G8 & 481.3 & 9.37 & 88.44 & 0.47 \\
G9 & 504.3 & 0.36 & 88.00 & -1.95 \\
G10 & 558.0 & -2.16 & 84.33 & -1.65 \\
G11 & 626.3 & -3.26 & 88.89 & 0.16 \\
G12 & 1415.9 & -14.64 & 88.67 & -0.95 \\
G13 & 526.7 & 4.64 & 91.33 & -1.23 \\
G14 & 1378.7 & -16.69 & 83.33 & 0.39 \\
G15 & 276.7 & -3.91 & 87.67 & -0.37 \\
G16 & 590.3 & 7.53 & 92.00 & 0.49 \\
G17 & 1115.6 & 2.97 & 85.00 & 0.62 \\
G18 & 856.0 & 1.38 & 87.78 & -0.89 \\
E1 & 650.6 & 8.54 & 85.44 & -3.70 \\
E2 & 645.2 & 16.22 & 89.37 & 2.58 \\
E3 & 696.4 & -24.76 & 86.80 & 1.12 \\
\hline
\end{tabular}

It is very important that sunflower seed quality be maintained at a high level in different production conditions (Mrđa et al., 2012). The same finding was obtained by Pacheco et al. (2005), who reported that sunflower seed is greatly influenced by environmental factors, which most often results in high variability, both among different years in a single location and among different locations in a single year as well as among different locations and years. The GR varied between $80.22 \%(\mathrm{G} 2)$ and $92.00 \%$ (G16). The general mean germination rate of the trial was $87.2 \%$ (Table 3). Some of the genotypes had mean values over this average value. Concerning years (E) the highest mean value for GR was stated in E2 (89.37\%), while the lowest in E1 (85.44\%), as shown in Table 3. The same finding was obtained by Pacheco et al. (2005), who reported that 
sunflower seed is greatly influenced by environmental factors, which most often results in high variability, both among different years in a single location and among different locations in a single year as well as among different locations and years.

AMMI is the best model in multi-environmental experiments. It provides an understanding of complex genotype by environment interactions (Gauch, 2006). AMMI1 biplot in our experiment showed that the sunflower genotypes were grouped on the basis of their reaction to environmental conditions which prevailed in the three-year period. From the AMMI1 biplot, it can be seen that it was a significant difference in GR for main effects $(G, E)$ and for the interaction $(G \times E)$. Lower IPCA values for genotypes (lines) and environments (years) suggest lower interaction level and therefore higher stability (Gauch, 2006). The genotypes G3, G11 and G15, with mean values higher than the general average (87.2\%) showed high stability for GR. Their position in relation to the abscissa indicates that it had similar GR in all environments. These genotypes contributed least to the $\mathrm{G} \times \mathrm{E}$ interaction, as they were closer to the center of origin of the axes. Genotypes G16 and G13, had the highest mean values for GR but had less stability. The genotypes farthest away from the graphic's origin contributed most to increase the $\mathrm{G} \times \mathrm{E}$ interaction for GR, such as G1, G2, G9 and G10 (Fig. 2).

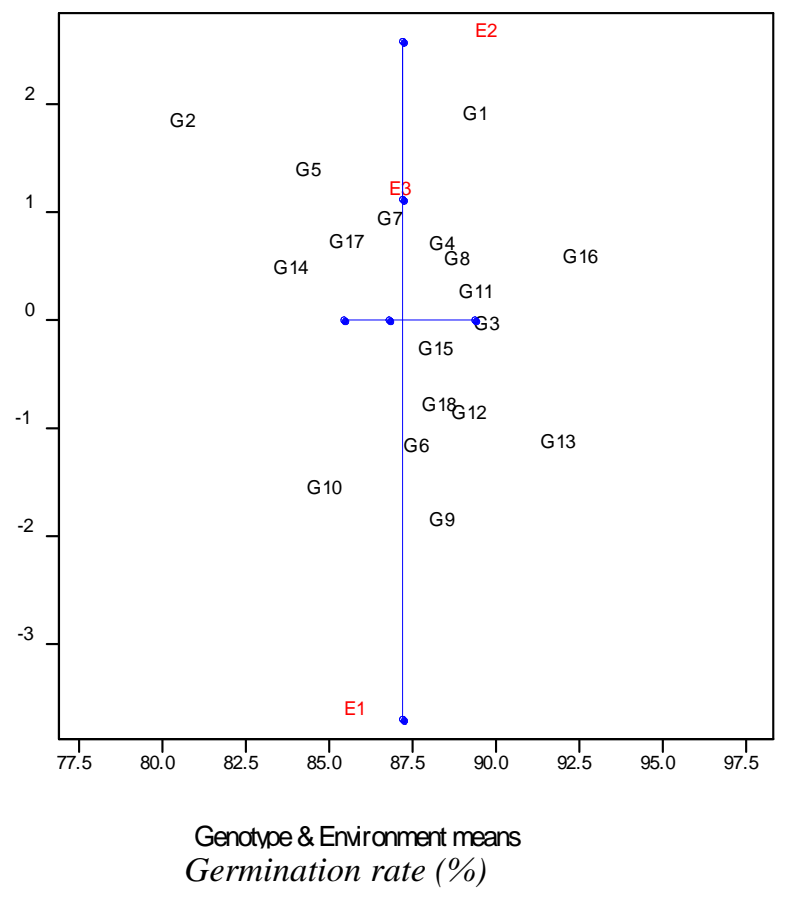

Figure 2. AMMI 1 biplot of 18 sunflower lines over three growing environments for germination rate

The lowest interaction effect was registered in E3, which was most stable in the three-year investigation. Genotypes with mean values on the average (G7) and over average $(\mathrm{G} 4, \mathrm{G} 8)$ showed positive interaction with E3. G1 showed highest interaction effect on the positive side of IPCA. The highest interaction on the negative side of IPCA was evident in G9. Negative interaction with E2 had genotype G10, with mean values lower than average. G10 showed positive interaction with the first year of the experiment. Close positions on the graph of the lines G4, G8 and G11 suggest that they require similar environmental conditions which can be used in seed production. Similar 
associations can be found between genotypes G6, G12 and G18. Among the environments, the highest level of stability was found in the E3, while the positions E1 and E2 at the ends of the graph suggest that they can be marked as very unstable for the trait of germination rate. Opposite positions of the environments E1 and E2 suggest that these environments have very different growing conditions for the examined trait.

\section{0 seed weight (TSW)}

It is very important that the sunflower hybrid seed, which is used for sowing, has a high value of thousand seed mass. Such seed conserve more food reserves and plants that develop from embryos grow faster, which is often very important in unfavorable agro-ecological conditions (Balalić et al., 2012). Considering the fact that there is a significant positive correlation between the mass of 1000 seeds and yield (Kaya et al., 2007), it is in interest to use hybrids with as high values of this trait. All sources of variation, main effects and interaction, for TSW were highly significant. TSW was predominantly influenced by the genotype (91.53\%). Year amounted to TSW with $1.10 \%$, and interaction with $7.41 \%$ (Table 2). The TSW varied from $28.3 \mathrm{~g}$ (G12) to $79.10 \mathrm{~g}(\mathrm{G} 2)$, with a mean average of $55.7 \mathrm{~g}$. The environment with highest TSW was E2 (57.9 g), while the E1 had the lowest average of TSW (53.9 g) (Table 4). Based on experiment carried out under Iranian conditions, the mass of 1000 seeds ranged between $36.0 \mathrm{~g}$ and $50.0 \mathrm{~g}$ (Beg et al., 2007), while the values obtained by Nel (2001) during the two-year experiment in the conditions of South Africa ranged between $59.4 \mathrm{~g} 78.5 \mathrm{~g}$. Based on a test of 13 hybrids during a four-year experiment in the conditions of central Italy, Laureti et al. (2007) obtained that the 1000 seeds average mass was $45.2 \mathrm{~g}$. Values closer to the stability line (0) indicate stabile genotypes or stable years in relation to genotypes. Genotypes G2, G4, G5, G6 and G7 were stable for TSW because their values are nearest to the line of stability (Fig. 3).

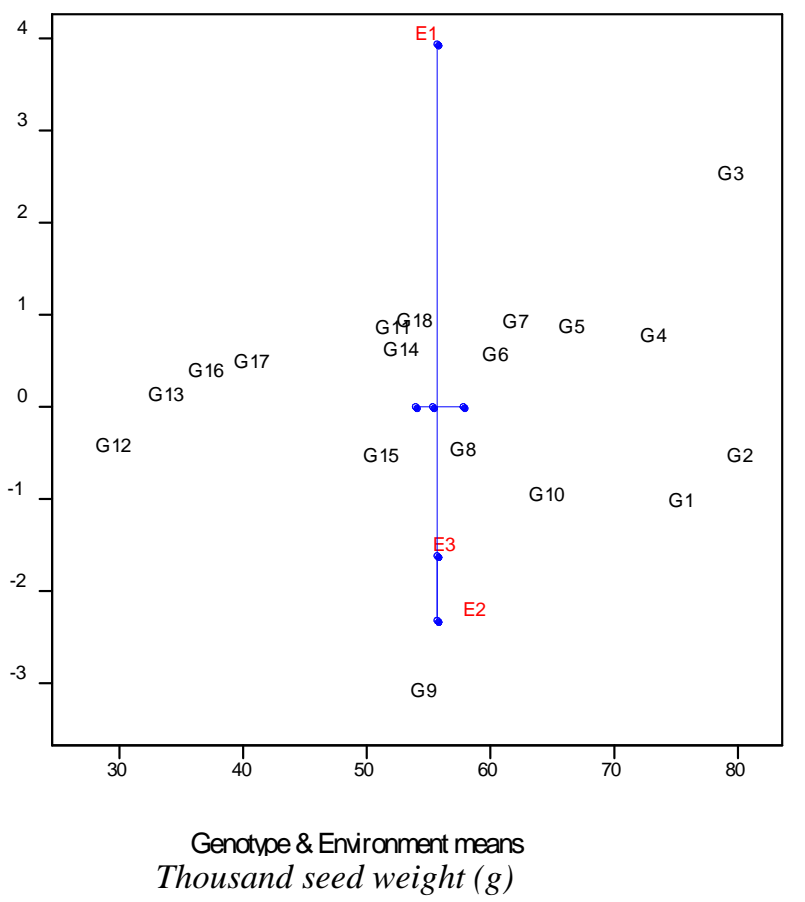

Figure 3. AMMI 1 biplot of 18 sunflower lines over three growing environments for thousand seed weight 
Table 4. Average values for 1000 seed weight (TSW) and protein content (PC) and first IPCA (interaction principal component axis) in sunflower lines

\begin{tabular}{c|c|c|c|c}
\hline Genotype & TSW $(\mathbf{g})$ & IPCA[1] & PC $(\boldsymbol{\%})$ & IPCA[1] \\
\hline G1 & 74.37 & -1.14 & 21.94 & 0.80 \\
G2 & 79.10 & -0.65 & 20.47 & 0.64 \\
G3 & 78.33 & 2.42 & 17.99 & 0.36 \\
G4 & 72.10 & 0.66 & 20.64 & 0.42 \\
G5 & 65.50 & 0.76 & 20.32 & 0.60 \\
G6 & 59.34 & 0.45 & 20.40 & 0.50 \\
G7 & 60.97 & 0.81 & 19.66 & 0.30 \\
G8 & 56.71 & -0.58 & 20.51 & 0.52 \\
G9 & 53.52 & -3.20 & 20.50 & 0.57 \\
G10 & 63.10 & -1.08 & 20.01 & 0.35 \\
G11 & 50.69 & 0.75 & 17.98 & -2.32 \\
G12 & 28.03 & -0.53 & 17.27 & -1.19 \\
G13 & 32.30 & 0.02 & 15.32 & 0.14 \\
G14 & 51.33 & 0.50 & 15.85 & -0.08 \\
G15 & 49.70 & -0.65 & 15.81 & 0.23 \\
G16 & 35.57 & 0.28 & 18.03 & -0.36 \\
G17 & 39.23 & 0.37 & 16.49 & -0.92 \\
G18 & 52.42 & 0.81 & 16.51 & -0.59 \\
E1 & 53.94 & 3.94 & 19.71 & -2.67 \\
E2 & 57.79 & -2.32 & 18.54 & 1.74 \\
E3 & 55.32 & -1.62 & 17.71 & 0.92 \\
\hline
\end{tabular}

They had also higher average values in relation to the general average (55.7 g). G3 showed high mean value for TSW, but it was unstable. The lines with the high levels of IPCA scores (Table 4) were G3, G9 and G12 which is in accordance with their positions on the graph. Genotypes G13 and G12 had very high stability for this trait, but the lowest mean values for TSW. Positive interaction for TSW was stated for G3, which had the highest value for this trait, but was very unstable. Genotypes G10, G8, G15 on the negative side of IPCA were in interaction with E2 and E3. E1 had the highest IPCA score and was highly unstable environment from the aspect of TSW. It had the highest positive interaction effect for TSW, and mean value on the average level. Environments E2 and E3 had similar mean values and stability. Values of all environments varied around the average TSW axis. Also, lines with similar IPCA results can be separated into specific groups such as lines G6, G7 and G5, also lines G14, G11 and G18 create another distinct association.

\section{Protein content $(P C)$}

The protein content ranges from 13-20\% in sunflower. Majority of existing proteins in fully developed seeds have structural or metabolic roles. Besides these roles, proteins in seeds also serve to provide a store of amino acids needed for germination and early seedling growth (Shewry et al., 1995). Results of ANOVA indicated that the main 
effects and interaction were highly significant for PC. The influence of genotype on PC amounted to $55.82 \%$, of the year to $9.26 \%$ and of interaction to $34.92 \%$ (Table 2). The values of the protein content were between $15.3 \%$ (G13) and $21.9 \%(\mathrm{G} 1)$. The general average value of the trial was $18.7 \%$. The environment with the highest protein content was E1 (19.7\%), while E3 (17.7\%) has the lowest average value for this trait (Table 4).

From the aspect of protein content, the lines with the most stable reaction in the examined environmental conditions were G7 and G10. They had a PC over general average (18.7\%) and were stable for this trait. High stability showed also G14, G15 and G13, but they had lowest mean values for PC. Genotype with the highest protein content was G1, but it was unstable. The environment with the lowest IPCA score for PC was E3. IPCA value of E2 was similar to E3 while the E1 had diametrically opposite reaction. It was the most unstable environment because it was furthest from the line of stability (0). G3 was in the positive interaction with E3. The most unstable environment was E1 because it was furthest from the line of stability (0). E2 had an average value on the general average. Specific groups of lines with similar IPCA scores such as G13, G15 and G14, also G2, G6, G8 and G9 can be marked out for they similar reaction to environmental conditions (Fig. 4).

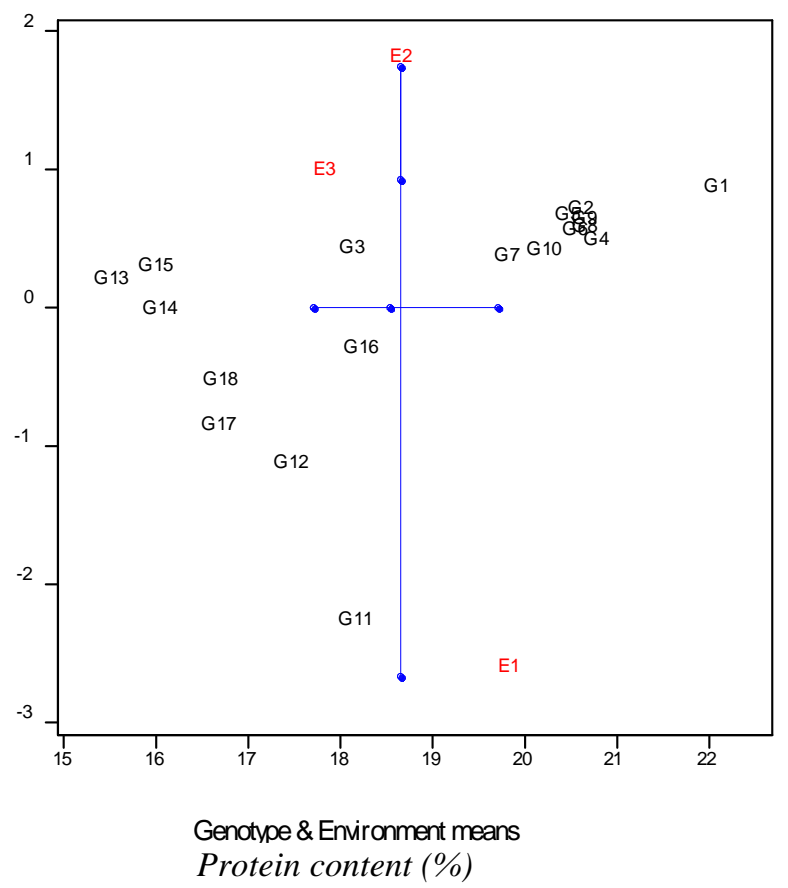

Figure 4. AMMI 1 biplot of 18 sunflower lines over three growing environments for protein content

An ideal genotype is defined as one that is the highest yielding across all test environments and is absolutely stable in performance, namely one that ranks the highest in all test environments (Yan et al., 2003; Pourdad and Moghaddam, 2013). Although such an ideal cultivar may not exist in reality, it can be used as a reference for cultivar evaluation. A genotype is more desirable if it is located closer to the ideal cultivar. Thus, using the ideal cultivar as the center, concentric circles were drawn to help visualize the distance between each genotype and the ideal cultivar (Yan, 2002; Pourdad and Moghaddam, 2013). 


\section{Conclusion}

On the basis of the analyses of seed yield, germination rate, thousand seeds weight:

The AMMI ANOVA indicated that main effects $(\mathrm{G}, \mathrm{E})$ were highly significant for SY, GR, TSW and PC. G $\times$ E interaction also was highly significant for all investigated traits, suggesting a differential response of genotypes (lines) across testing environments (years).

Highest mean values for yield and stability had genotypes G12, G14 and G17. The genotypes G3, G11 and G15, with mean values higher than the general average showed high stability for GR. Environment E3 was most stable for GR in the three-year investigation. Genotypes G2, G4, G5, G6 and G7 were stable for TSW because their values were nearest to the line of stability. Environments E2 and E3 had similar mean values and stability for TSW. From the aspect of protein content, the lines with the most stable reaction in the examined environmental conditions were G7 and G10. For PC the environment E3 was most stable. The method successfully integrate the attributes measured in the multi-environment trial. The analysis helps the breeder make decisions in favor of moderate to high seed yield, 1000 seed weight and protein content with good seed germination to moderate sunflower hybrids in general or in selected environments. The combination of analysis of variance and principal component analysis in the AMMI model, along with the prediction assessment, is a valuable approach for understanding genotype $\times$ environment interaction.

Based on the obtained results we can conclude that sunflower lines G2, G12 and G14 developed at Institute of Field and Vegetable Crops Novi Sad are suitable for high yield production and all other observed parameters. Crossing this lines Institute created new hybrids NS FELIKS and NS KRUNA (both hybrids were registered in the EU and Serbia). The seeds of these hybrids Institute of Field and Vegetable Crops sales in the domestic and foreign markets. A further objective of this research will be observation of new created lines and their behavior in different years of production.

Acknowledgements. This research is part of the project 31025: Development of new varieties and production technology improvement of oil crops for different purposes, sponsored by the Ministry of Education, Science and Technological Development of the Republic of Serbia.

\section{REFERENCES}

[1] Adugna, W., Labushange, M. T. (2002): Genotype-environment interactions and phenotypic stability analysis of linseed in Ethiopia. - Plant Breeding 121(1): 66-71.

[2] Balalić, I., Crnobarac, J., Miklič, V. (2010): Interaction hybrid $\times$ planting date for oil yield in sunflower. - Journal of Agricultural Science 55(1): 9-16.

[3] Balalić, I., Zorić, M., Crnobarac, J. (2012): Interpretacija interakcije hibrida i roka setve za masu 1000 semena suncokreta. - Ratarstvo i povrtarstvo 49(3): 229-235.

[4] Beg, A., Pourdad, S. S., Pala, M., Oweist, T. (2007): Effect of supplementary irrigation and variety on yield and some agronomic characters of sunflower grown under rainfed conditions in northern Syria. - Helia 30(47): 87-98.

[5] Branković, G., Balalić, I., Zorić, M., Miklič, V., Jocić, S., Šurlan Momirović, G. (2012): Characterization of sunflower testing environments in Serbia. - Turkish Journal of Agriculture and Forestry 36(3): 275-283. 
[6] Ceretta, S., van Eeuwijk, F. (2008): Grain yield variation in malting barley cultivars in Uruguay and its consequences for the design of a trials network. - Crop Science 48(1): 167-180.

[7] Denčić, S., Mladenov, N., Kobiljski, B. (2011): Effects of genotype and environment on breadmaking quality in wheat. - International Journal of Plant Production 5(1): 71-82.

[8] Donohue, K. (2009): Completing the cycle: maternal effects as the missing link in plant life histories. - Philosophical Transactions of the Royal Society B: Biological Sciences 364(1520): 1059-1074.

[9] García-Peńa, M., Arciniegas-Alarcón, S., Basford, K., dos Santos Dias, C. T. (2016): Analysis of sunflower data from a multi-attribute genotype $\times$ environment trial in Brazil. - International Journal of Agricultural and Biological Sciences 11(2): 127-139.

[10] Gauch, H. G. (1988): Model selection and validation for yield trials with interaction. Biometrics 44(3): 705-715.

[11] Gauch, H. G. Jr. (2006): Statistical analysis of yield trials by AMMI and GGE. - Crop Science 46(4): 1488-1500.

[12] He, H., de Souza Vidigal, D., Snoek, L. B., Schnabel, S., Nijveen, H., Hilhorst, H., Bentsink, L. (2014): Interaction between parental environment and genotype affects plant and seed performance in Arabidopsis. - Journal of Experimental Botany 65(22): 66036615.

[13] ISTA Rules (2014): International Rules for Seed Testing. - International Seed Testing Association, Zurich.

[14] Kadhem, F. A. (2014): Additive main effect and multiplicative interaction analysis of yield stability performance in sunflower genotypes grown in Iraqi environment. - The Iraqi Journal of Agriculture Science 45(8): 932-939.

[15] Kaya, Y., Evci, G., Durak, S., Pekcan, V., Gücer, T. (2007): Determining the relationships between yield and yield attributes in sunflower. - Turkish Journal of Agriculture and Forestry 31(4): 237-244.

[16] Kaya, M. D., Akdogãn, G., Kulan, E. G., Dağhan, H., Sari, A. (2019): Salinity tolerance classification of sunflower and safflower. - Applied Ecology and Environmental Research 17(2): 3849-3857.

[17] Laureti, D., Del Gatto, A., Pieri, S. (2007): Commercial sunflower hybrid evaluation in east central Italy. - Helia 30(47): 141-144.

[18] Mahmood, H. N., Towfiq, S. I., Rashid, K. A. (2019): The sensitivity of different growth stages of sunflower (Helianthus annuum.) under deficit irrigation. - Applied Ecology and Environmental Research 17(2): 7605-7623.

[19] Marinković, R., Jocković, M., Marjanović-Jeromela, A., Jocić, S., Ćirić, M., Balalić, I., Sakač, Z. (2011): Genotype by enviroment interactions for seed yield and oil content in sunflower (H. annuum) using AMMI model. - Helia 34(54): 79-88.

[20] Marjanović-Jeromela, A., Nagl, N., Gvozdanović-Varga, J., Hristov, N., Kondić-Špika, A., Vasić, M., Marinković, R. (2011): Genotype by environment interaction for seed yield per plant in rapeseed using AMMI model. - Pesquisa Agropecuaria Brasileira 46(2): 174-181.

[21] Miklič, V., Dušanić, N., Jocić, S. (2011): Sunflower Seed Production. - In: Milošević, M., Kobiljski, B. (eds.) Seed Production. Vol 2. Institute of Field and Vegetable Crops, Novi Sad, pp. 196-264 (in Serbian).

[22] Mrđa, J., Crnobarac, J., Radić, V., Miklič, V. (2012): Sunflower seed quality and yield in relation to environment conditions of production region. - Helia 35(57): 123-134.

[23] Musavi, S. M. N., Hejazi, P., Khalkhali, S. K. Z. (2016): Study on stability of grain yield sunflower cultivars by AMMI and GGE bi plot in Iran. - Molecular Plant Breeding 7(2): $1-6$.

[24] Nel, A. A. (2001): Determinants of sunflower seed quality for processing. - Ph. D. Diss. Univ. of Pretoria, Pretoria, Republic of South Africa. http://upetd.up.ac.za/thesis/available/etd-09012001-132144/ (accessed on 21 Aug 2014). 
[25] Oliveira, E. J., Godoy, I. J. (2006): Pod yield stability analysis of runner peanut lines using AMMI. - Crop Breeding and Applied Biotechnology 6(4): 311-317.

[26] Oliveira, E. J., Xavier de Freitas, J. P., Nunes de Jesus, O. (2014): AMMI analysis of the adaptability and yield stability of yellow passion fruit varieties. - Scientia Agricola 71(2): 139-145.

[27] Pacheco, R. M., Duarte, J. B., Vencovsky, R., Pinheiro, J. B., Oliviera, A. B. (2005): Use of supplementary genotypes in AMMI analysis. - Theoretical and Applied Genetics 110(5): 812-818.

[28] Pourdad, S. S., Moghaddam, M. J. (2013): Study on seed yield stability of sunflower inbred lines through GGE biplot. - Helia 36(58): 19-28.

[29] Rauf, S., Jamil, N., Tariq, S. A., Khan, M., Kausar, M., Kaya, Y. (2017): Progress in modification of sunflower oil to expand its industrial value. - Journal of the Science of Food and Agriculture 97(7): 1997-2006.

[30] Sabaghnia, N., Janmohammadi, M. (2016): Biplot analysis of silicon dioxide on early growth of sunflower. - Plant Breeding and Seed Science 73(1): 87-98.

[31] Shewry, R. P., Napier, A. J., Tatham, S. A. (1995): Seed storage proteins: structures and biosynthesis. - The Plant Cell 7(7): 945-956.

[32] Sial, M. M., Arain, M., Ahmad (2000): Genotype $\times$ environment interaction on bread wheat grown over multiple sites and years in Pakistan. - Pakistan Journal of Botany 32(1): 85-92.

[33] Thangavel, P., Anandan, A., Eswaran, R. (2011): AMMI analysis to comprehend genotype-by-environment $(\mathrm{G} \times \mathrm{E})$ interactions in rainfed grown mungbean (Vigna radiata L.). - Australian Journal of Crop Science 5(13): 1767-1775.

[34] Yan, W. (2002): Singular- value partitioning for biplot analysis of multienvironment trial data. - Agronomy Journal 94(5): 990-996.

[35] Yan, W., Hunt, L. A. (2003): Biplot Analysis of Multienvironment Trial Data. - In: Kang, M. S. (ed.) Quantitative Genetics, Genomics, and Plant Breeding. CAB International, Wallingford, Oxon, UK, pp. 289-313.

[36] Yan, W., Kang, M. S. (2003): GGE Biplot Analysis: A Graphical Tool for Breeders, Geneticists and Agronomists. 1st Ed. - CRC Press, Boca Raton, FL.

[37] Yan, W., Kang, M. S., Ma, B., Woods, S., Cornelius, P. L. (2007): GGE Biplot vs. AMMI analysis of genotype-by-environment data. - Crop Science 47(2): 641-653. 